\title{
EXPERIMENTAL AND THEORETICAL STUDIES OF 4-[(4-METHYL-5-PHENYL- 4H1,2,4-TRIAZOL-3-YL)SULFANYL]BENZENE-1,2-DICARBONITRILE
}

\author{
Ufuk Çoruh, ${ }^{1 *}$ Reşat Ustabaş, ${ }^{2}$ Hakkı Türker Akçay, ${ }^{3}$ Emre Menteşe, ${ }^{3}$ Ezequiel M. Vazquez Lopez ${ }^{4}$ \\ ${ }^{1}$ Computer Education and Instructional Technology Department, Education Faculty, \\ Ondokuz Mayls University, 55200-Atakum-Samsun, Turkey \\ ${ }^{2}$ Department of Middle Education, Education Faculty, Ondokuz Mayls University, \\ 55200-Atakum-Samsun, Turkey \\ ${ }^{3}$ Department of Chemistry, Faculty of Sciences, Recep Tayyip Erdoğan University, 53100, Rize, Turkey \\ ${ }^{4}$ Departamento de Química Inorganica, Universidade de Vigo, Vigo 36310, Galicia, Spain \\ ucoruh@gmail.com
}

In this study, 4-[(4-methyl-5-phenyl-4H-1,2,4-triazol-3-yl)sulfanyl]benzene-1,2-dicarbonitrile was synthesized and its molecular structure was characterized by means of FT-IR and X-ray diffraction methods. The crystal is monoclinic and belongs to the P21/n space group. There are three weak intermolecular $\mathrm{C}-\mathrm{H} \ldots \mathrm{N}$ type hydrogen bonds in the molecular structure. The geometrical parameters, vibration frequencies, HOMO-LUMO energies, and molecular electrostatic potential (MEP) map of the compound (3) in ground state were calculated by using density functional theory (DFT/B3LYP) with the 6-311G(d) basis set. Calculated geometrical parameters were compared with X-ray diffraction geometric parameters. On the other hand, theoretical and experimental FT-IR results were also compared.

Keywords: crystal structure; 1,2,4-triazole; DFT calculations; molecular electrostatic potential; frontier orbitals

\section{ЕКСПЕРИМЕНТАЛНИ И ТЕОРЕТСКИ ИСПИТУВАЫА НА 4-[(4-МЕТИЛ-5-ФЕНИЛ-4Н1,2,4-ТРИАЗОЛ-3-ИЛ)СУЛФАНИЛ]БЕНЗЕН-1,2-ДИКАРБОНИТРИЛ}

Во ова истражување беше синтетизиран 4-[(4-метил-5-фенил-4H1,2,4-триазол-3-ил)сулфанил]бензен-1,2-дикарбонитрил, а неговата структура беше карактеризирана со помош на FT-IR и рендгенска дифракција. Кристалот е моноклиничен и припаѓa на просторната група P21/n. Во молекулската структура постојат три слаби интермолекулски водородни врски од типот на C-H...N. Геометриските параметри, вибрациските фреквенции, енергиите на HOMO-LUMO и мапата на молекулскиот електростатички потенцијал (МЕР) на соединението (3) во основна состојба беа пресметани со теоријата на функционалот на густината (DFT/B3LYP) и основен сет 6-311G(d). Пресметаните геометриски параметри беа споредени со геометриските параметри добиени со рендгенската дифракција. Исто така беа споредени и теоретските и експерименталните резултати добиени со FT-IR.

Клучни зборови: кристална структура; 1,2,4-триазол; DFT пресметки; молекулски електростатички потенцијал; гранични орбитали 


\section{INTRODUCTION}

1,2,4-triazoles, planar five-membered heterocyclic compounds with a $6 \pi$ aromatic system, have an important role in synthetic chemistry. In particular, the pharmacological properties of this compound class have been extensively studied. It is known that these compounds show anti-inflammatory, antiviral, antimicrobial and antidepressant activities [1]. In addition, 1,2,4-triazole derivatives are potential chemosensors for the determination of many metal cations [2-11].

In this study, compound (3) was synthesized and its molecular structure was characterized by using FT-IR, X-ray diffraction, and quantum chemical methods. The geometrical parameters, vibration frequencies, molecular electrostatic potential, and frontier orbitals of compound (3) were calculated in the ground state by using DFT/B3LYP/6-311G(d). A comparison of the calculated geometric parame- ters with the experimental parameters of compound (3) was carried out.

\section{EXPERIMENTAL SECTION}

\subsection{Synthesis}

Dry DMF solution of 4-methyl-5-phenyl4H-1,2,4-triazole-3-thiol (1) (0.61 g, $3.2 \mathrm{mmol})$ and 4-nitrophthalonitrile (2) (0.55 g, $3.2 \mathrm{mmol})$ were stirred for $10 \mathrm{~min}$ at $55{ }^{\circ} \mathrm{C}$ under $\mathrm{N}_{2}$ atmosphere. Dry potassium carbonate $(0.48 \mathrm{~g}, 3.5 \mathrm{mmol})$ was added to the reaction mixture for two hours and the reaction was conducted under $\mathrm{N}_{2}$ atmosphere at $50{ }^{\circ} \mathrm{C}$ for 5 days. Then it was poured into ice-water. The creamy solid precipitate was filtered, washed with water, and dried in vacuum. Single crystals were obtained in acetone/petroleum ether solvent system. The yield was $0.71 \mathrm{~g}(70 \%)$.

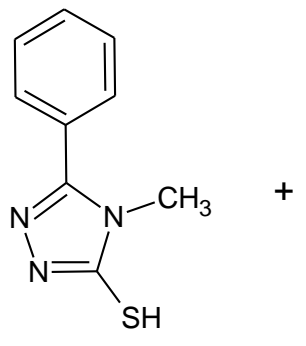

(1)

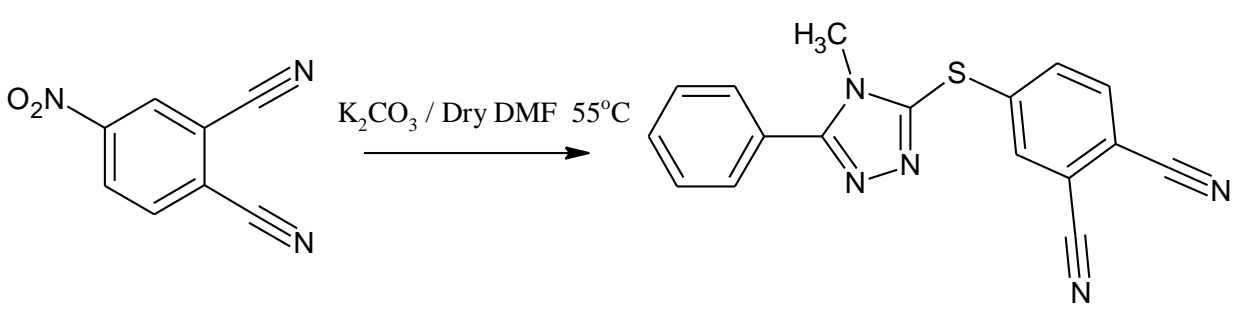

(2)
(3)

Scheme 1. Synthesis route of compound (3)

\subsection{Measurements and calculations}

We used the Schlenk system, where all reactions were carried out under dry and oxygen-free nitrogen atmosphere. DMF (dimethylformamide) was dried and purified in accordance with the literature [12]. 4-methyl-5-phenyl-4H-1,2,4-triazole-3thiol was prepared according to the literature [13]. A Perkin Elmer Spectrum One FT-IR device with the ATR technique was used for IR recordings. The Xray data of compound (3) were measured on a Bruker Smart CCD area-detector diffractometer by using $\mathrm{CuK} \alpha(\lambda=1.54178 \AA) \mathrm{X}$-rays. For data collection and cell refinement, the APEX2 [14] and Bruker SAINT [14] programs were used respectively. SHELXS-97 [15], SHELXL-97 [15], ORTEP III [16], and WinGX software [17] programs were used to solve and refine the structure, to define the molecular figures, and to prepare material for publication. Crystallographic data are given in Table 1.

All the theoretical calculations were performed by using the Gaussian 03 [18] program package. The initial atomic coordinates of compound (3) were obtained by means of X-ray data. Via the GaussView [19] molecular visualization program, the geometry of the molecule in three dimensions was defined. DFT calculations were performed with the 6-311G(d) basis set by using B3LYP [20,21] (Becke's three-parameter hybrid functional using the LYP correlation functional) hybrid function. In order to calculate the vibration frequencies of the optimized structure, DFT/B3LYP methods and the 6-311G(d) basis set were used. The 0.9672 [22] scale value was used for the calculated vibration frequencies.

\section{RESULTS AND DISCUSSION}

\subsection{Crystal structure}

Compound (3) is a monoclinic system belonging to the $\mathrm{P} 21 / \mathrm{n}$ space group. The molecular structure of the title compound, which is obtained 
by using the ORTEP-3 program, is shown in Figure 1. Furthermore, the package diagram of compound (3) is given in Figure 2. The compound consists of one triazole and two benzene rings. When examining the bond lengths under the X-ray parameters of compound (3) in Table 3, it can be seen that especially C38-N32 [1.136 (2) ̊], C37$\mathrm{N} 31[1.144(2) \AA], \mathrm{C} 3-\mathrm{S} 31[1.743$ (2) $\AA], \mathrm{N} 1-\mathrm{N} 2$
[1.381(2) $\AA]$, and N2-C3 [1.307(2) $\AA]$ are in conformity with the values in the literature [23-26]. The dihedral angles between the 1,2,4 triazole ring and the $\mathrm{C} 31-\mathrm{C} 36$ and $\mathrm{C} 51-\mathrm{C} 56$ rings are $76.92^{\circ}$ and $27.53^{\circ}$ respectively. The crystal structure has three weak intermolecular $\mathrm{C}-\mathrm{H} . . \mathrm{N}$ type hydrogen bonds. The details related to these interactions are given in Table 2.

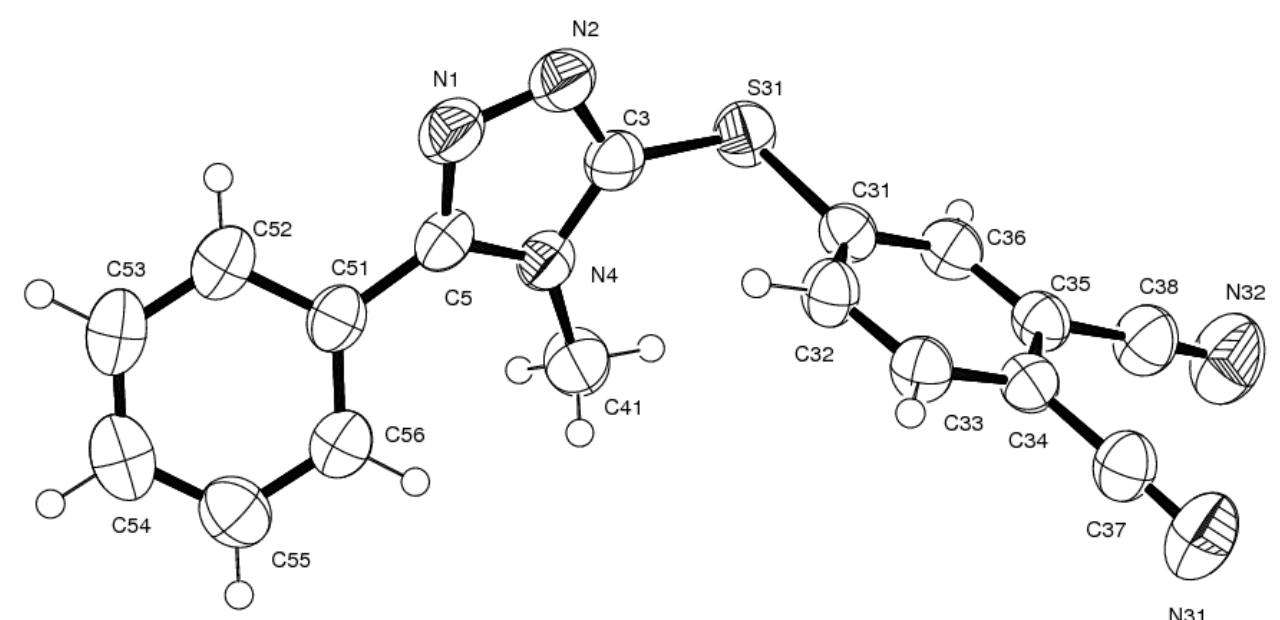

Fig. 1. Ortep-3 diagram of (3) with atom labeling

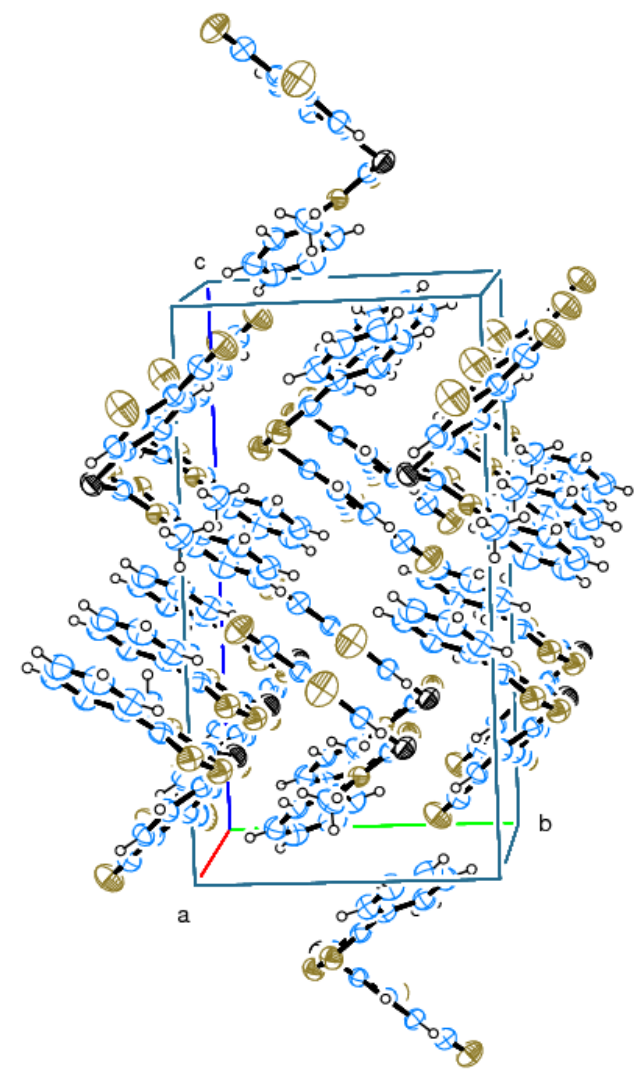

Fig. 2. Packing diagram of the title compound 


\section{Table 1}

Crystallographic data for compound (3)

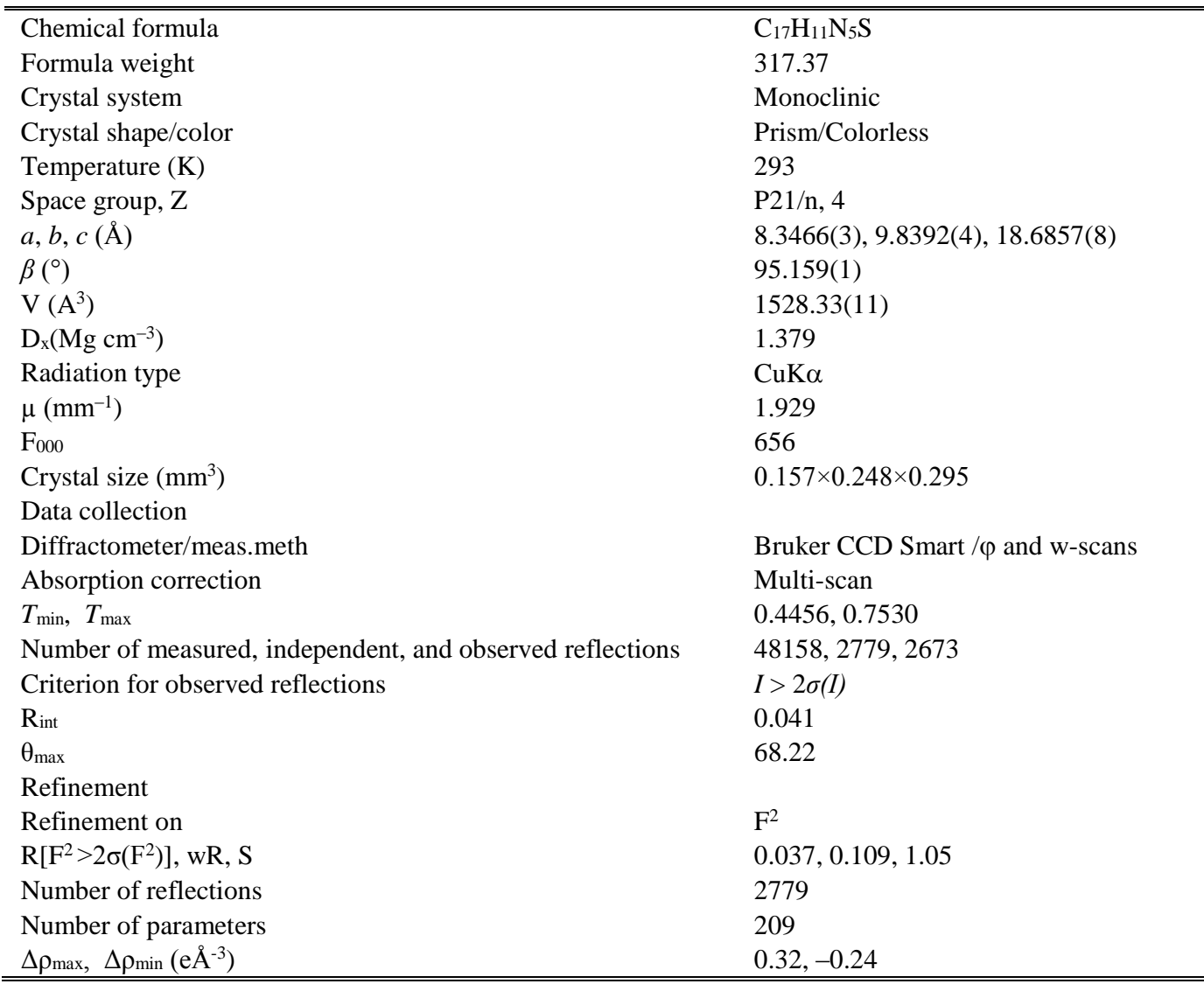

Table 2

Hydrogen-bond geometry $\left(A,{ }^{\circ}\right)$

\begin{tabular}{lllll}
\hline \hline D-H $-\mathbf{A}$ & D-H & H $\cdots \mathbf{A}$ & D $\cdots \mathbf{A}$ & D-H $\cdots \mathbf{A}$ \\
\hline C54-H54 $\cdots \mathrm{N} 32^{\mathrm{i}}$ & $0.93(2)$ & $2.93(2)$ & $3.836(3)$ & $163(1)$ \\
$\mathrm{C} 53-\mathrm{H} 53 \cdots \mathrm{N} 31^{\mathrm{i}}$ & $0.93(2)$ & $2.76(2)$ & $3.452(2)$ & $131(1)$ \\
$\mathrm{C} 41-\mathrm{H} 41 \mathrm{~B} \cdots \mathrm{N} 31^{\mathrm{ii}}$ & $0.96(2)$ & $2.70(2)$ & $3.447(3)$ & $134(1)$ \\
\hline \hline
\end{tabular}

Symmetry code: (i) $\mathrm{x}-1 / 2-1,-\mathrm{y}+1 / 2, \mathrm{z}-1 / 2$; (ii) $\mathrm{x}-1 / 2,-\mathrm{y}+1 / 2, \mathrm{z}-1 / 2$

\subsection{Optimized structures}

In order to constitute the initial geometry of compound (3) for theoretical calculations, the experimental results of X-ray diffraction are used. To obtain the geometrical optimization of compound (3), the DFT/B3LYP method and 6-311G(d) basis set are used. Experimental and calculated geometrical parameters, bond lengths, bond angles, and torsion angles for compound (3) are given in Table 3. To compare the consistency of the calculated and experimental geometric parameters, the RMSE values are found. These values are $0.014 \AA$ for bond lengths and $0.78^{\circ}$ for bond angles. As can be seen in Table 3, the greatest deviations in C31-S31 bond length and C3-S31-C31 bond angles are found to be $0.032 \AA$ and $1.27^{\circ}$.

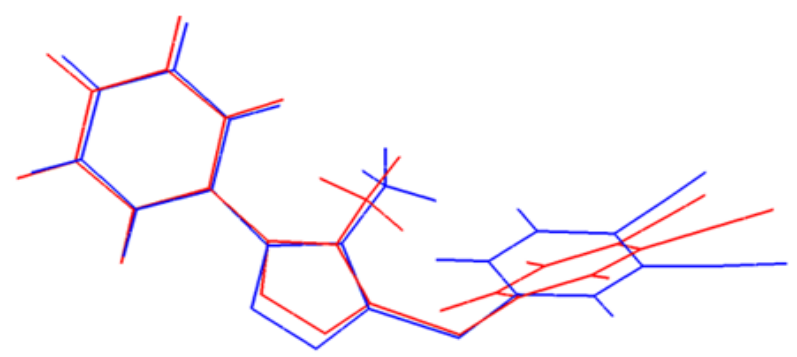

Fig. 3. Superposition of molecular conformation of (3) as established from X-ray (red) and DFT calculation (blue) 
T a ble 3

Theoretical and experimental molecular structure parameters

\begin{tabular}{|c|c|c|}
\hline & X-ray & B3LYP/6-311G(d) \\
\hline \multicolumn{3}{|l|}{ Bond Lengths( $(\AA)$} \\
\hline C38-N32 & 1.136 & 1.154 \\
\hline C37-N31 & 1.144 & 1.154 \\
\hline C34-C37 & 1.431 & 1.428 \\
\hline C35-C36 & 1.381 & 1.399 \\
\hline C31-C32 & 1.390 & 1.398 \\
\hline $\mathrm{C} 31-\mathrm{S} 31$ & 1.767 & 1.799 \\
\hline C3-S31 & 1.743 & 1.763 \\
\hline $\mathrm{C} 3-\mathrm{N} 2$ & 1.307 & 1.313 \\
\hline $\mathrm{C} 3-\mathrm{N} 4$ & 1.366 & 1.380 \\
\hline N4-C41 & 1.459 & 1.459 \\
\hline $\mathrm{N} 4-\mathrm{C} 5$ & 1.366 & 1.373 \\
\hline $\mathrm{N} 1-\mathrm{C} 5$ & 1.322 & 1.322 \\
\hline $\mathrm{N} 1-\mathrm{N} 2$ & 1.381 & 1.363 \\
\hline C5-C51 & 1.465 & 1.469 \\
\hline C51-C52 & 1.393 & 1.402 \\
\hline \multicolumn{3}{|l|}{ Bond angles $\left({ }^{\circ}\right)$} \\
\hline C55-C56-C51 & 120.32 & 120.38 \\
\hline C3-S31-C31 & 102.80 & 101.53 \\
\hline $\mathrm{C} 3-\mathrm{N} 4-\mathrm{C} 5$ & 104.77 & 104.04 \\
\hline C3-N4-C41 & 125.65 & 126.85 \\
\hline C5-N4-C41 & 129.58 & 128.96 \\
\hline N31-C37-C34 & 178.32 & 178.55 \\
\hline C32-C31-C36 & 120.30 & 120.06 \\
\hline C32-C31-S31 & 123.12 & 122.02 \\
\hline C36-C31-S31 & 116.57 & 117.80 \\
\hline C35-C36-C31 & 119.49 & 120.30 \\
\hline $\mathrm{C} 5-\mathrm{N} 1-\mathrm{N} 2$ & 108.16 & 108.18 \\
\hline $\mathrm{N} 1-\mathrm{C} 5-\mathrm{N} 4$ & 109.40 & 109.78 \\
\hline N1-C5-C51 & 123.55 & 123.48 \\
\hline N4-C5-C51 & 126.94 & 126.71 \\
\hline $\mathrm{C} 3-\mathrm{N} 2-\mathrm{N} 1$ & 106.51 & 107.52 \\
\hline $\mathrm{N} 2-\mathrm{C} 3-\mathrm{N} 4$ & 111.17 & 110.45 \\
\hline N2-C3-S31 & 123.87 & 124.90 \\
\hline N4-C3-S31 & 124.74 & 124.63 \\
\hline N32-C38-C35 & 177.20 & 178.41 \\
\hline \multicolumn{3}{|l|}{ Torsion angles $\left({ }^{\circ}\right)$} \\
\hline C51-C56-C55-C54 & -1.7 & -0.29 \\
\hline C3-S31-C31-C32 & -14.0 & -39.5 \\
\hline S31-C31-C32-C33 & -177.0 & -177.2 \\
\hline $\mathrm{N} 2-\mathrm{N} 1-\mathrm{C} 5-\mathrm{N} 4$ & -0.07 & 0.01 \\
\hline N2-N1-C5-C51 & -176.3 & -178.6 \\
\hline C31-C32-C33-C34 & 0.0 & 1.1 \\
\hline N1-C5-C51-C56 & -154.2 & -143.8 \\
\hline N1-N2-C3-S31 & 174.8 & 179.6 \\
\hline $\mathrm{C} 5-\mathrm{N} 4-\mathrm{C} 3-\mathrm{N} 2$ & 0.0 & -0.3 \\
\hline
\end{tabular}

Furthermore, the superposition of the atomic positions of compound (3), which are obtained by theoretical and experimental methods, is shown in Figure 3. The RMSE value is calculated as $0.32 \AA$. The calculated dihedral angles between the 1,2,4 triazole ring and the $\mathrm{C} 31-\mathrm{C} 36$ and $\mathrm{C} 51-\mathrm{C} 56$ rings of the molecular structure that is formed after the optimization of compound (3) are $76.56^{\circ}$ and $35.41^{\circ}$ respectively. The theoretical and experimental values of the dihedral angles are close to each other

\subsection{Vibrational spectra}

Characteristic $\mathrm{C}-\mathrm{H}$ stretching vibrations of aromatic structures are observed between 3000 and $3150 \mathrm{~cm}^{-1}$. In this study, the vibrations observed at 3115 and $3077 \mathrm{~cm}^{-1}$ are calculated to be at 3092 and $3084 \mathrm{~cm}^{-1}$ and show good agreement with the literature. The $\mathrm{C}-\mathrm{H}_{3}$ stretching vibrations are observed at 3047 and $2923 \mathrm{~cm}^{-1}$ in the experimental IR spectrum in accordance with the literature. Also, they are calculated to be at 3033 and $2961 \mathrm{~cm}^{-1}$ [27-29]. C $\equiv \mathrm{N}$ stretching vibration in the phthalonitrile ring is seen expressly at $2200-2300 \mathrm{~cm}^{-1}$ as a sharp peak. The theoretical $\mathrm{C} \equiv \mathrm{N}$ stretching vibrations were calculated to be at 2265 and $2269 \mathrm{~cm}^{-1}$ and were observed at $2231 \mathrm{~cm}^{-1}$.

The reason why only one sharp peak was observed in the theoretical and experimental spectra may be due to two $\mathrm{C} \equiv \mathrm{N}$ stretching vibrations that are very near to each other [30-32].

The bending vibrations that occur inside the aromatic and aliphatic planes given in the literature are in the range of $1480-1000 \mathrm{~cm}^{-1}$. In our study, the vibrations observed at $1486-1079 \mathrm{~cm}^{-1}$ are calculated to occur at $1480-1104 \mathrm{~cm}^{-1}$ and are characterized as $\mathrm{C}-\mathrm{H}$ bending vibrations in plane. All these results are in good agreement with the associated literature [30, 31, 33, 34].

The stretching vibrations $v(\mathrm{C}=\mathrm{C})$ and $v(\mathrm{C}=\mathrm{N})$ which belong to the phenyl and triazole groups were calculated to be at 1572, 1530, 1454, 1445, 1382, 1270 , and $1196 \mathrm{~cm}^{-1}$ and were observed at 1587 , $1565,1456,1428,1329,1262$, and $1206 \mathrm{~cm}^{-1}$, in agreement with the literature [35-36].

The C-H out-of-plane bending wagging at the phenyl and triazole rings is observed at about 675$1000 \mathrm{~cm}^{-1}$. In this study, the peaks calculated to be at 1104, 1085, 1010, 902, 837, 762, 712, and 687 $\mathrm{cm}^{-1}$ are matched with the peaks observed at 1079 , 1056, 991, 901, 853, 772, 719, and $693 \mathrm{~cm}^{-1}$ and defined as wagging [30, 35, 36]. CCC (in-plane bending) vibration is observed at about $1000 \mathrm{~cm}^{-1}$. We defined this vibration experimentally at $991 \mathrm{~cm}^{-1}$ and also theoretically at $1010 \mathrm{~cm}^{-1}[32,37]$. 


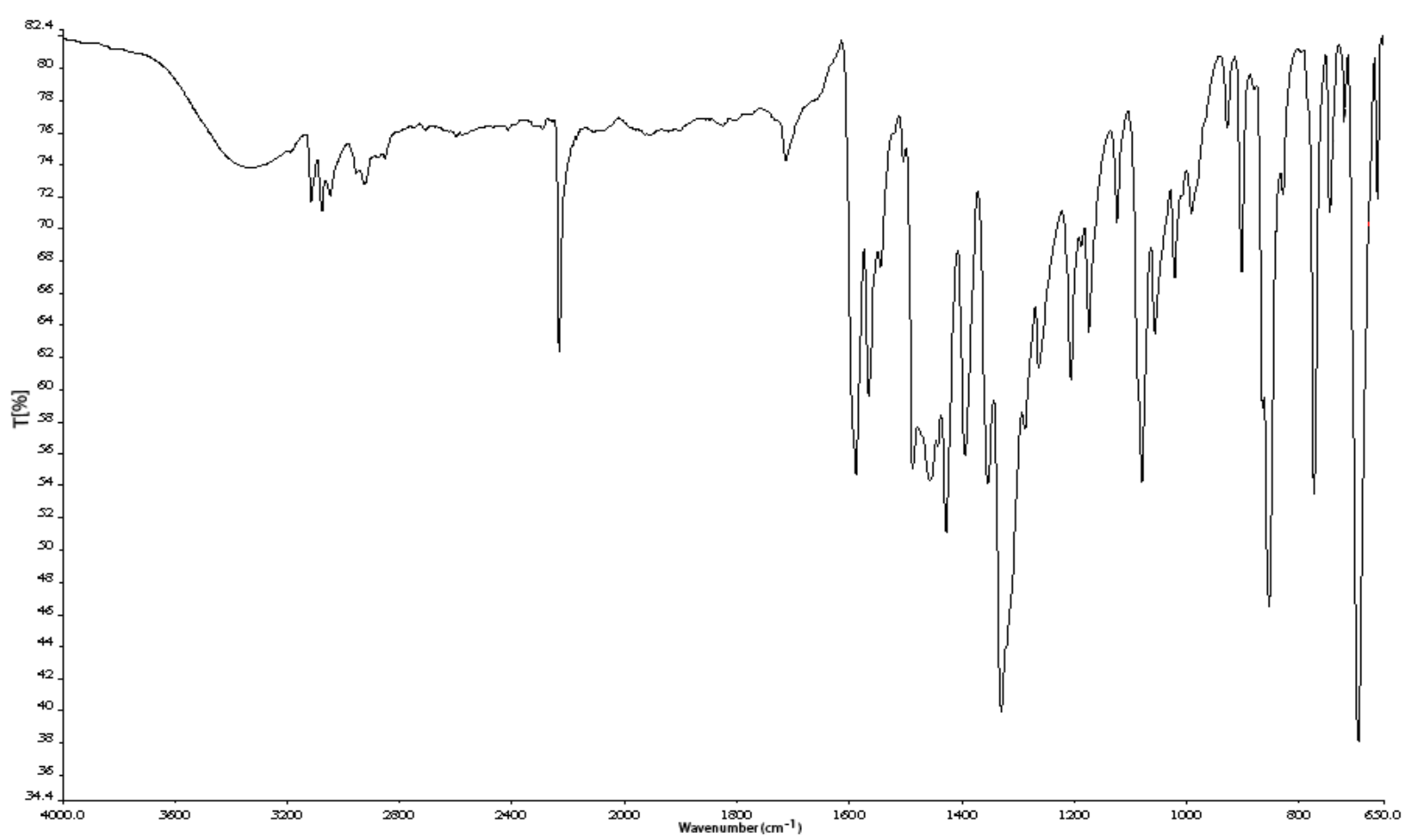

Fig. 4. Experimental IR spectrum of the compound (3)

Table 4

Values of the experimental and calculated vibrational frequencies $\left(\mathrm{cm}^{-1}\right)$

\begin{tabular}{lcc}
\hline \hline Assignments ${ }^{a}$ & Experimental & Calculated \\
\hline$v(\mathrm{C}-\mathrm{H}) \mathrm{s}$ & 3115 & 3092 \\
$v(\mathrm{C}-\mathrm{H}) \mathrm{s}$ & 3077 & 3084 \\
$v(\mathrm{C}-\mathrm{H} 3)$ as & 3047 & 3033 \\
$v(\mathrm{C}-\mathrm{H} 3) \mathrm{s}$ & 2923 & 2961 \\
$v(\mathrm{C} \equiv \mathrm{N}) \mathrm{s}$ & 2231 & 2265 \\
$v(\mathrm{C}=\mathrm{C})$ & 1587 & 1572 \\
$v(\mathrm{C}=\mathrm{C})$ & 1565 & 1530 \\
$\gamma(\mathrm{C}-\mathrm{H})+\omega(\mathrm{C}-\mathrm{H} 3)$ & 1486 & 1480 \\
$v(\mathrm{C}=\mathrm{N})+\gamma(\mathrm{C}-\mathrm{H})+\omega(\mathrm{C}-\mathrm{H} 3)$ & 1456 & 1454 \\
$\gamma(\mathrm{C}-\mathrm{H})+\omega(\mathrm{C}-\mathrm{H} 3)+v(\mathrm{C}-\mathrm{C})$ & 1428 & 1445 \\
$\gamma(\mathrm{C}-\mathrm{H})+\omega(\mathrm{C}-\mathrm{H} 3)$ & 1394 & 1425 \\
$v(\mathrm{C}=\mathrm{N})+v(\mathrm{C}-\mathrm{N})+\omega(\mathrm{C}-\mathrm{H} 3)+\gamma(\mathrm{C}-\mathrm{H})$ & 1329 & 1382 \\
$v(\mathrm{C}-\mathrm{C})$ & 1262 & 1270 \\
$\gamma(\mathrm{C}-\mathrm{H})+v(\mathrm{C}-\mathrm{CN})$ & 1206 & 1196 \\
$\gamma(\mathrm{C}-\mathrm{H})$ & 1174 & 1172 \\
$v(\mathrm{C}-\mathrm{S})+\omega(\mathrm{C}-\mathrm{H} 3)+\gamma(\mathrm{C}-\mathrm{H})$ & 1079 & 1104 \\
$v(\mathrm{~N}-\mathrm{N})+\omega(\mathrm{C}-\mathrm{H} 3)$ & 1056 & 1085 \\
$v(\mathrm{C}-\mathrm{S})$ & 1021 & 1061 \\
$\beta(\mathrm{CCC})+\omega(\mathrm{C}-\mathrm{H} 3)$ & 991 & 1010 \\
$\omega(\mathrm{C}-\mathrm{H})$ & 901 & 902 \\
$\omega(\mathrm{C}-\mathrm{H})$ & 853 & 837 \\
$\omega(\mathrm{C}-\mathrm{H})+\tau(\mathrm{CCCN})$ & 772 & 762 \\
$\omega(\mathrm{C}-\mathrm{H})+\tau(\mathrm{CCNN})$ & 719 & 712 \\
$\omega(\mathrm{C}-\mathrm{H})$ & 693 & 687 \\
\hline \hline
\end{tabular}

${ }^{a} v$, stretching; $\gamma$, rocking; $\omega$, wagging; $\beta$, bending; $\tau$, torsion; s, symmetric; as, asymmetric 


\subsection{Frontier molecular orbital and molecular electrostatic potential}

By means of the DFT/B3LYP method applied on the optimized structure derived from the 6-311G(d) basis set, the frontier molecular orbitals and MEP map are obtained. As can be seen in Figure 5 , the HOMO is generally concentrated on the $1,2,4$ triazole and phenyl rings. On the other hand, LUMO is concentrated on the phthalonitriles ring system. HOMO and LUMO have energy levels of -7.08 and $-2.69 \mathrm{eV}$ respectively. Gap $=E_{\text {Hомо }}-$ $E_{\mathrm{Lumo}}$, and hardness $=\mathrm{Gap} / 2$ [38]. The HOMOLUMO energy difference is $4.39 \mathrm{eV}$ and the hardness of the molecule corresponds to $2.19 \mathrm{eV}$.

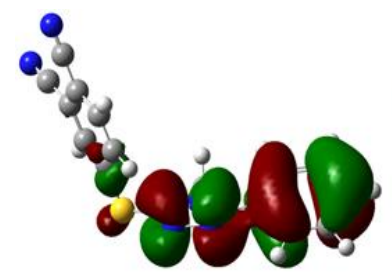

HOMO $(-7.08 \mathrm{eV})$

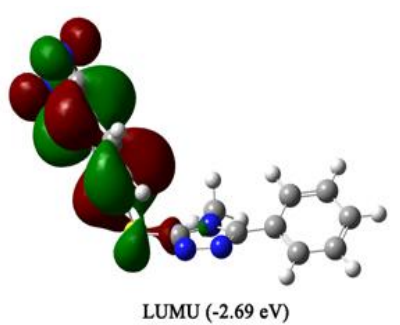

LUMU $(-2.69 \mathrm{eV})$
Fig. 5. Molecular orbital surfaces and energy levels using the DFT/B3LYP method for the HOMO and LUMO of compound (3)

The molecular electrostatic potential (MEP) is calculated considering the electrical charge of the related molecule. We can define electronegative and electropositive locations looking at these results as well as hydrogen bonding interactions [39-41]. The MEP map of compound (3) is shown in Figure 6.

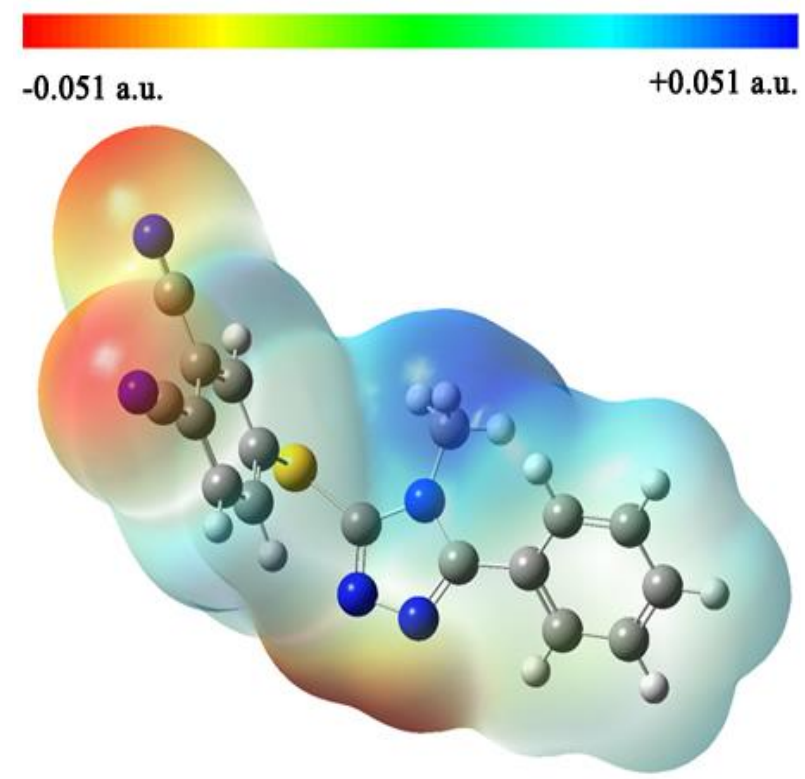

Fig. 6. Appearance of the molecular electrostatic potential (MEP) map of compound (3)
When examining the map, it can easily be seen that negative (red) partitions are mainly concentrated on cyano groups and on $\mathrm{N} 1$ and $\mathrm{N} 2$ atoms of the 1,2,4 triazole ring. These negative $\mathrm{V}(\mathrm{r})$ values are -0.05 a.u for N31, -0.048 a.u for N32, -0.049 a.u for N1, and -0.048 a.u for N2. The largest positive (blue) partition is located around the methyl group and its $\mathrm{V}(\mathrm{r})$ value is 0.038 a.u.

The MEP map provides the information that the molecular interactions will take place in these regions. Examining Table 2, this prediction about the interaction locations can be confirmed.

\section{CONCLUSIONS}

4-[(4-methyl-5-phenyl-4H-1,2,4-triazol-3-yl) sulfanyl]benzene-1,2-dicarbonitrile(3), formulated as $\mathrm{C} 17 \mathrm{H} 11 \mathrm{~N} 5 \mathrm{~S}$, was synthesized and its molecular structure was characterized by means of FT-IR and $\mathrm{X}$-ray diffraction methods. The calculated geometrical parameters in ground state obtained via the DFT/ B3LYP method with the 6-311G(d) basis set were compared with geometric parameters obtained via the X-ray diffraction experimental method and a very small difference was observed. Some small differences between theoretical calculations and experimental results are seen because the theoretical methods used consider a molecule alone unless there are interactions between neighbouring molecules in crystal form. Also, the experimental and calculated vibration frequencies were compared with each other and were found to be in compliance. The HOMO-LUMO energy gap was calculated as $4.39 \mathrm{eV}$.

\section{Supplementary data}

Further information can be obtained from the Cambridge Crystallographic Data Centre (Email:deposit@ccdc.cam.ac.uk), where the crystal structure X-ray data of compound (3) are stored under depository number CCDC-1441403.

Acknowledgement. The author would like to thank the Higher Education Council for supporting this study within international research.

\section{REFERENCES}

[1] A. K. Srivastava, A. Kumar, N. Misra, P. S. Manjula, B. K. Sarojini, B. Narayana, Synthesis, spectral (FT-IR, UV-visible, NMR) features, biological activity prediction and theoretical studies of 4-Amino-3-(4hydroxybenzyl)-1H-1,2,4-triazole-5(4H)-thione and its tautomer, Journal of Molecular Structure, 1107, 137144 (2016). 
[2] J-L. Zhao, H. Tomiyasu, C. Wu, H. Cong, X. Zeng, S. Rahman, P. E. Georghiou, D. L. Hughes, C. Redshaw, T. Yamato, Synthesis, crystal structure and complexation behaviour study of an efficient $\mathrm{Cu}^{2+}$ ratiometric fluorescentchemosensor based on thiacalix[4]arene,Tetrahedron, 71, 8521-8527 (2015)

[3] A. N. Gusev, V. F. Shulgin, S. B. Meshkova, S. S. Smola, W. Linert, A novel triazole- based fluorescent chemosensor for zinc ions, Journal of Luminescence, 155, 311-316 (2014).

[4] J. Zhang, C. Yu, S. Qian, G. Lu, J. Chen, A selective fluorescent chemosensor with 1,2,4-triazole as subunit for $\mathrm{Cu}(\mathrm{II})$ and its application in imaging $\mathrm{Cu}(\mathrm{II})$ in living cells, Dyes and Pigments, 92, 1370-1375 (2012).

[5] D. Mandal, A. Thakur, S. Ghosh, A triazole tethered triferrocene derivative as a selective chemosensor for mercury(II) in aqueous environment, Polyhedron, 52, 1109-1117 (2013).

[6] N-J. Wang, C-M. Sun, W-S. Chung, A specific and ratiometric chemosensor for $\mathrm{Hg}^{2+}$ based on triazole coupled ortho-methoxyphenylazocalix[4]arene, Tetrahedron, 67, 8131-8139 (2011).

[7] Y-J. Zhang, X-P. He, M. Hu, Z. Li, X-X. Shi, G-R. Chen, Highly optically selective and electrochemically active chemosensor for copper(II) based on triazolelinked glucosyl anthraquinone, Dyes and Pigments, $\mathbf{8 8}$, 391-395 (2011).

[8] T-J. Jia, W. Cao, X-J. Zheng, L-P. Jin, A turn-on chemosensor based on naphthol-triazole for $\mathrm{Al}(\mathrm{III})$ and its application in bioimaging, Tetrahedron Letters, 54, 3471-3474 (2013).

[9] S. Joshi, S. Kumari, R. Bhattacharjee, A. Sarmah, R. Sakhuja, D. D. Pant, Experimental and theoretical study: Determination of dipole moment of synthesized coumarin-triazole derivatives and application as turn off fluorescence sensor: High sensitivity for iron(III) ions, Sensors and Actuators B: Chemical, 220, 1266-1278 (2015).

[10] N-J. Wang, C-M. Sun, W-S. Chung, A highly selective fluorescent chemosensor for $\mathrm{Ag}^{+}$based on calix[4]arene with lower-rim proximal triazolylpyrenes, Sensors and Actuators B: Chemical, 171-172, 984-993 (2012).

[11] J-H. Ye, J. L, Z. Wang, Y. Bai, W. Zhang, W. He, A new $\mathrm{Fe} 3+$ fluorescent chemosensor based on aggregation-induced emission, Tetrahedron Letters, 55, 36883692 (2014).

[12] D. D. Perin, W. L. F. Armarego, Purification of laboratory chemicals, Pergamon, Oxford, 1989.

[13] J. M. Kane, M. A. Staeger, C. R. Dalton, F. P. Miller, M. W. Dudley, A. M. L. Ogden, J. H. Kehne, H. J. Ketteler, T. C. McCloskey, Y. Senyah, P. A. Chmielewski, J. A. Miller, 5-Aryl-3-(alkylthio)-4H- 1,2,4-triazoles as Selective Antagonists of Strychnine-Induced Convulsions and Potential Antispastic Agents, J. Med. Chem., 37, 125132 (1994)

[14] Bruker (2009). APEX2 and SAINT. Bruker AXS Inc., Madison, Wisconsin, USA.

[15] G. M. Sheldrick, SHELXS97 and SHELXL97, University of Göttingen, Germany, 1997.
[16] L. J. Farrugia, ORTEP-3 for Windows - A version of ORTEP-III with a Graphical User Interface (GUI), $J$. Appl. Cryst., 30, 565 (1997).

[17] L. J. Farrugia, WinGX suite for small-molecule singlecrystal crystallography, J. Appl. Cryst., 32, 837-838 (1999).

[18] M. J. Frisch, G. W. Trucks, H. B. Schlegel, G. E. Scuseria, M. A. Robb, J. R. Cheeseman, J. A. Montgomery Jr., J. T. Vreven, K. N. Kudin, J. C. Burant, J. M. Millam, S. S. Iyengar, J. Tomasi, V. Barone, B. Mennucci, M. Cossi, G. Scalmani, N. Rega, G. A. Petersson, H. Nakatsuji, M. Hada, M. Ehara, K. Toyota, R. Fukuda, J. Hasegawa, M. Ishida, T. Nakajima, Y. Honda, O. Kitao, H. Nakai, M. Klene, X. Li, J. E. Knox, H. P. Hratchian, J. B. Cross, V. Bakken, C. Adamo, J. Jaramillo, R. Gomperts, R. E. Stratmann, O. Yazyev, A. J. Austin, R. Cammi, C. Pomelli, J. W. Ochterski, P. Y. Ayala, K. Morokuma, G. A. Voth, P. Salvador, J. J. Dannenberg, V. G. Zakrzewski, S.Dapprich, A. D. Daniels, M. C. Strain, O. Farkas, D. K. Malick, A. D. Rabuck, K.Raghavachari, J. B. Foresman, J. V. Ortiz, Q. Cui, A. G. Baboul, S. Clifford, J.Cioslowski, B. B. Stefanov, G. Lui, A. Liashenko, P. Piskorz, I. Komaromi, R. L. Martin, D. J. Fox, T. Keith, M. A. Al-Laham, C. Y. Peng, A. Nanayakkara, M. Challacombe, P. M. W. B. Gill, B. Johnson, W. Chen, M. W. Wong, C. Gonzalez, J. A. Pople, GAUSSIAN 03, Revision E.01, Gaussian Inc., Wallingford CT, 2004

[19] R. Dennington II, T. Keith, J. Millam, Gauss View Version 4.1 2, Semichem, Inc., Shawnee Mission, KS, 2007.

[20] P. J. Stephens, F. J. Devlin, C. F. Chablowski, M. J. Frisch, Ab Initio Calculation of Vibrational Absorption and Circular Dichroism Spectra Using Density Functional Force Fields, J. Phys. Chem., 98, 11623-11627 (1994).

[21] C. Peng, P.Y. Ayala, H. B. Schlegel, M. J. Frisch, Using redundant internal coordinates to optimize equilibrium geometries and transition states, J. Comput. Chem., 17, 49-56 (1996).

[22] J. P. Merrick, D. Moran, L. Radom, An Evaluation of Harmonic Vibrational Frequency Scale Factors, J. Phys. Chem., A 111, 11683-11700 (2007).

[23] H. K. Fun, M. Hemamalini, N. Kalluraya, B. Kalluraya, 4-(\{[4-Amino-5-(4-chloroanilinomethyl)-4H-1,2,4-triazol-3-yl]sulfanyl \}acetyl)-3-(4-methoxyphenyl)-1,2,3oxadiazol-3- ium-5-olate, Acta Cryst. E66, o3178 (2010)

[24] H. T. Akçay, R. Bayrak, E. Şahin, K. Karaoğlu, Ü. Demirbaş, Experimental and computational studies on 4[(3,5-dimethyl-1H-pyrazol-1-yl)methoxy]phthalonitrile and synthesis and spectroscopic characterization of its novel phthalocyanine magnesium(II) and tin(II) metal complexes, Spectrochimica Acta, Part A: Molecular and Biomolecular Spectroscopy, 114, 531-540 (2013).

[25] A. A. El-Emam, S. Lahsasni, H. H. Asiri, C. K. Quah, H. K. Fun, 2-\{[5-(Adamantan-1-yl)-4-methyl-4H- 1,2,4triazol-3-yl]sulfanyl $\}$-N,N-dimethylethanamine, Acta Cryst., E67, o1356(2012).

[26] H. Tuncer, A. O. Görgülü, T. Hökelek, 4-(Furan-2ylmethoxy)benzene-1,2-dicarbonitrile, Acta Cryst. E68, o153 (2012). 
[27] A. A. El-Emam, A-M. S. Al-Tamimi, K. A. Al-Rashood, H. N. Misra, V. Narayan, O. Prasad, L. Sinha, Structural and spectroscopic characterization of a novel potential chemotherapeutic agent 3-(1-adamantyl)-1-\{[4-(2-methoxyphenyl)piperazin-1-yl]methyl $\}-4-m e t h y l-1 \mathrm{H}-1,2, \quad 4-$ triazole-5(4H)-thione by first principle calculations, Journal of Molecular Structure, 1022, 49-60 (2012).

[28] M. Koparir, C. Orek, P. Koparir, K. Sarac, Synthesis, experimental, theoretical characterization and biological activities of 4-ethyl-5-(2-hydroxyphenyl)-2H-1,2,4triazole-3(4H)-thione, Spectrochimica Acta Part A: Molecular and Biomolecular Spectroscopy, 105, 522-531 (2013).

[29] E. Düğdü, Y. Ünver, D. Ünlüer, H. Tanak, K. Sancak, Y. Köysal, Ş. Işık, Synthesis, structural characterization and comparison of experimental and theoretical results by DFT level of molecular structure of 4-(4-methoxyphenethyl)-3,5-dimethyl-4H-1,2,4-Triazole, Spectrochimica Acta Part A: Molecular and Biomolecular Spectroscopy, 108, 329-337 (2013).

[30] H. T. Akçay, R. Bayrak, S. Karslioglu, E. Sahin, Synthesis, characterization and spectroscopic studies of novel peripherally tetra-imidazole substituted phthalocyanine and its metal complexes, the computational and experimental studies of the novel phthalonitrile derivative, Journal of Organometallic Chemistry, 713, 1-10 (2012).

[31] H. T. Akcay, R. Bayrak, E. Sahin, K. Karaoglu, U. Demirbas, Experimental and computational studies on 4[(3,5-dimethyl-1H-pyrazol-1-yl)methoxy]phthalonitrile and synthesis and spectroscopic characterization of its novel phthalocyanine magnesium(II) and tin(II) metal complexes, Spectrochimica Acta Part A: Molecular and Biomolecular Spectroscopy, 114, 531-540 (2013).

[32] A. Coruh, F. Y1lmaz, B. Sengez, M. Kurt, M. Cinar, M. Karabacak, Synthesis, molecular conformation, vibrational, electronic transition, and chemical shift assignments of 4-(thiophene-3-ylmethoxy)phthalonitrile: a combined experimental and theoretical analysis, Struct. Chem., 22, 45-56 (2011).
[33] M. Karabacak, Z. Cinar, M. Kurt, S. Sudha, N. Sundaraganesan, FT-IR, FT-Raman, NMR and UV-vis spectra, vibrational assignments and DFT calculations of 4-butyl benzoic acid, Spectrochim. Acta A, 85, 179-189 (2012).

[34] S. Muthu, E. E. Porchelvi, Experimental spectroscopic (FTIR, FT-Raman, FT-NMR, UV-Visible) and DFT studies of 1-ethyl-1,4-dihydro-7-methyl-4oxo-1,8 naphthyridine-3-carboxylic acids, Spectrochim. Acta A, 116, 220-235 (2013).

[35] H. T. Akcay, R. Bayrak, Computational studies on the anastrozole and letrozole, effective chemotherapy drugs against breast cancer, Spectrochimica Acta, Part A: Molecular and Biomolecular Spectroscopy, 122, 142-152 (2014).

[36] S. Qiu, J. Wei, F. Pan, J. Liu, A. Zhang, Vibrational, NMR spectrum and orbital analysis of 3,30,5,50tetrabromobisphenol A: A combined experimental and computational study, Spectrochim. Acta A, 105, 38-44 (2013).

[37] M. Kandasamy, G. Velraj, S. Kalaichelvan, Vibrational spectra, NMR and HOMO-LUMO analysis of 9fluorenone-2-carboxylic acid, Spectrochim. Acta A, 105, 176-183(2013).

[38] Pearson, R. G, Density functional theory-electronegativity and hardness chemtracts, Inorg. chem., 3, 317-333 (1991).

[39] E. Scrocco, J. Tomasi, Electronic Molecular Structure, Reactivity and Intermolecular Forces: An Euristic Interpretation by Means of Electrostatic Molecular Potentials, Adv. Quant. Chem., 11, 115-193 (1979).

[40] F. J. Luque, J. M. Lopez, M. Orozco, Perspective on Electrostatic interactions of a solute with a continuum. A direct utilization of ab initio molecular potentials for the prevision of solvent effects, Theor. Chem. Acc., 103, 343-345(2000)

[41] N. Okulik, A. H. Jubert, Internet Electron. J. Mol. Des., 4, 17-30(2005). 
